\title{
DETERMINATION OF THE FACTORS AFFECTING AIRFREIGHT AND MAPPING SIMILAR COUNTRIES VIA MULTIDIMENSIONAL SCALING
}

\author{
Tüzün Tolga İNAN (D) ${ }^{1, *}$, Neslihan GÖKMEN (1) ${ }^{2}$ \\ ${ }^{1}$ Pilotage Department, School of Applied Sciences, Bahcesehir University, Istanbul, Turkey \\ ${ }^{2}$ Basic Sciences Department, Maritime Faculty, Istanbul Technical University, Istanbul, Turkey
}

Received 17 August 2020; accepted 20 January 2021

\begin{abstract}
As long as people and freights need to move from one place to another, the civil aviation industry will always exist. In this study, a country-based examination has been made on total airfreight transport. Also, gross domestic product (GDP) and total population data were included in this study. 50 countries were selected according to the most recent value that included the years 2018 or 2019 and 26 of these were included in the analysis which was covered in all three rankings. The purpose of the study is to find the similarities between countries based on the total airfreight transportation, total GDP, and total population. The relationship between the three parameters was examined with the correlation analysis. Afterward, the associated parameters were taken as independent variables and the total airfreight transportation variable was modeled by multiple linear regression analysis. In light of these analyses, GDP and total population have a significant impact on total airfreight transportation. To check the assumptions related to outliers, residuals are determined. To show the outliers and the similarities of the countries clearly, the multidimensional scaling method is used. Multidimensional scaling configuration shows that Turkey and the United Kingdom have similarities in terms of total airfreight numbers.
\end{abstract}

Keywords: airfreight transport, gross domestic product, total population, multidimensional scaling.

\section{Introduction}

Airfreight is a term for carrying freights in national and international transportation that includes short to long distances. The other meaning of airfreight is related to the loading of goods with an air carrier. Airfreight service is the most precious one considering express loadings around the world. Just as the commercial or passenger airlines, freight airlines fly in identical routes. Airfreight, on the other hand, infers the sum to be paid for the transportation of commodities by air. When goods are carried from one place to another, the sum of the payment for the movement of the commodities is described as freight. So, airfreight is related to the fees paid for air transportation (Saloodo, 2020).

In this study, the most recent yearly total airfreight numbers are taken for selected 26 countries, so this data included both the inbound and outbound freights. Besides, airfreight is a term related to the transportation of dangerous, perishable, and specific cargoes. Airfreight transportation is a specified type of module for carrying precious and featured cargoes in the most rapid way. Although the concept of airfreight transportation started after the beginning of civil aviation, it has entered into a trend of development with the process of differentiated passenger transportation and strategies that develop in line with the low-cost transportation strategy. The trend of this development includes both passenger airlines carrying freight near luggage and combination airlines operating with airfreight aircraft alongside passenger aircraft. Airfreight companies such ad FedEx have revealed that carry the airfreight from the airport to the airport also operated as an integrator with a door-to-door delivery strategy. This strategy has also a relationship with companies such as DHL, UPS, and TNT. With the understanding of globalization in trade since the beginning of the 2000s, international airfreight transportation has shown a continuous and big upward trend under the concept of the supply chain. Since the beginning of the 2000s, airfreight transportation worldwide has increased by $4.5-5.0 \%$ per year (Airbus, 2014; Boeing, 2014). It is seen that airfreight transportation will have the potential for continuing its progress in the coming years. This is because of the strategy of liberalization (application of free circulation between countries to develop economical welfare) that developed with the understanding of globalization. So that,

${ }^{\star}$ Corresponding author. E-mail: tuzuntolga.inan@sad.bau.edu.tr 
the supply-demand balance continues to develop based on the implementation of the open skies agreement on increased long-haul flights and the liberalization of airspace used on international flights (Alves \& Forte, 2015; Poret et al., 2015; Wang \& Heinonen, 2015).

Airlines are the main providers of airfreight transportation. Airlines have generally implemented the airport to airport transportation strategy. The main providers of airfreight transportation are classified as; airfreight forwarders, air freight companies, customs brokers, airfreight terminals, and ground handling companies. The first process in the airfreight transportation system is related to the customs and the other processes have a relationship with the stages of preparation, packing, and loading of the airfreights. Most airlines carry out both passenger and freight transportation together. However, the process of airfreight operations after the airfreight is unloaded from the aircraft enables airfreight carriers to be sent to buyers by using outsourcing under the name of airfreight forwarders. As a result, the airfreight transportation process which includes a large number of providers and procedures is based on the ability to make decisions using different strategies at the international level which are in high demand. The decision of which airline strategies can be used more effectively to increase their loading capacity and financial income is of great importance for the operations to be carried out most accurately. Contrary to the stable and accepted capacity of passenger seats, the concept of utilizing airfreight space in expressions of assignment and demand is more uncertain for application (Kasilingam, 1996; Morrell, 2012). In light of this detailed information, airfreight transportation plays a critical role in countries' economical situations. So, the study aims to examine the locations of similar countries by determining the factors that affect the number of airfreight transportation of countries. The content of this manuscript, it is started with a theoretical framework related to airfreight in general, secondly, airfreight transportation model and the concept of the combinational airline are explained, and thirdly the concept of business models in airfreight transportation are mentioned. In the study objective and research methodology part, the selected countries for the analysis are defined with the concept of ICAO Council Members (International Civil Aviation Organization [ICAO] Council, 2020a). In the methodology part, correlation analysis, multiple linear regression model, and multidimensional scaling are introduced. In the conclusion section, all statistical results are revealed and the study is completed with results notes.

\section{Theoretical framework}

Total airfreight numbers have a relationship between the economical welfare of countries which described as GDP and the total population is a term that triggers GDP. In addition to this information, airfreight charges are complicated and based on the gross weight and/or volume of the airfreight that is related to economical welfare. Because of this, it is taken these parameters to specify the relationship between airfreight and the country's' economical welfare. There has a small number of researches related to this study such as Artar et al. (2016). These researches revealed that not only airfreight transportation but also passenger transportation has a positive impact on the GDP.

According to IATA's (International Air Transport Association) list of airfreight rates, the unit price decreases while the paid weight per shipment increases. So, airfreight carriers take into account both weight and volume while counting up airfreight charges. Because of this situation, it is important to evaluate the connection between the two concepts while determining the airfreight area. So, the effective use of airfreight volume on the aircraft is important for increasing financial income. For example, an aircraft where the airfreight volume is not filled may not take off due to excessively heavy loading. This situation reveals the need to calculate the weight balance related to the floor correctly even if a heavy load is required. In contrast, when an aircraft carries a high but light load, this will cause an increase in curb weight capacity. Because the total load weight in the airfreight compartments is much less than the maximum weight of the aircraft, but the airfreight area has attained full capacity. Therefore, the acceptance of balanced amounts of heavy and light airfreight provides more loadable space and increased amounts of financial income (International Air Transport Association, 2020). In this way, weights increase as shipment and airlines generate more revenue on a financial basis under the concept of airfreight transportation. This is related to the percentage of large and small volumes of airfreight that total revenues carry under the concept of airfreight transportation, supply-demand balance, and price determination. If it is summarized in terms of airfreight charges; multiple factors and constraints should be taken into account as airfreight transportation involves complex processes in terms of determining loading volumes and shipping charges (Chao \& Li, 2017).

The examination of the factors affecting airfreight income is classified due to the limited volume of airfreight of narrow-body aircraft (single-aisle passenger aircraft) and the passenger aircraft which carry the airfreight next to the luggage. In this case, the loading limitations of the aircraft airfreight area are determined under the criteria of fuel, the number of passengers, and the amount of luggage. In wide-body aircraft, the usage of ULDs is varied depending on the different weight and volume restrictions on aircraft types. Airlines determine their pieces of information about reservation based on the number of ULD and pallet (equipment for the transportation of special airfreight on wide-body aircraft) and the types of aircraft. The increasing airfreight demand in recent years is dependent on aircraft types. Because of this; it is important to examine the selection of airfreight conformity, the capacity, the receipt, and transportation of the deliveries regardless of the number of ULD and pallets (Vancroonenburg et al., 2014; Lurkin \& Schyns, 2015). 
For the structural safety of aircraft, there are weight limits for each compartment in the airfreight compartment. While airlines accept airfreight for transportation, they evaluate bulky heavy airfreight instead of bulky light airfreight depending on the number of pallets and carrying capacities of ULDs.' Felix T.S. Chan has provided a two-step smart judgment assistance system for the loading problem in airfreight flights. According to this system, a new approach has been developed for airfreight transportation. In this approach, differently shaped and sized pallets are loaded on the aircraft based on the 3D loading plan. For the airfreight that is loaded in this way, the load capacity of the aircraft in the airfreight compartments is evaluated under the 3D system as well as visual decision and specified volume indicators (Chan et al., 2006). This system is provided for the most accurate evaluation of operational model constraints based on the cost model for ULD and the loading plan of pallets. The results obtained are shown in the model and resolution practice that will be beneficial for airfreight carriers (Yan et al., 2008). For the airfreight income administration problem, Huang and Chang improved a solution algorithm based on approximation of the anticipated income function in the dynamic programming model (DPM) for stochastic capacity and shipping weight (Huang \& Chang, 2010). According to this model, the acceptance and refusal options of the reservation for airlines can be evaluated under certain criteria. In this model named Markov, it is aimed to calculate the decision of whether the reservation requests are accepted as a reference for the airlines with the allocation of aircraft airfreight capacities, random weight, and volume (Han et al., 2010).

For the answer to such objections, a rising amount of theoretical research has been implemented to send out the problems in air cargo operations since the 1990s. Although, most problems with the real world civil aviation remain insufficient to be resolved. So, the airfreight companies have implemented new strategies related to the difficulties and the problems of airfreight operations (Feng et al., 2015). Because of this situation, the old western airfreight companies (DHL, UPS, and FedEx) have entered into the Asia market which is really in developing trends. Because these airfreight companies are the best example of the transition of the airport to airport service to door to door service. These airfreight companies are also named as integrators that implement the whole process of freights such as packaging, transportation, and distribution (Clutch, 2020).

\section{Airfreight transport model and the concept of combinational airline}

In the airfreight transportation model, combinational airlines are defined as offering both passenger and airfreight transportation services together. The priority is passenger transportation which airfreights are transported alongside luggage on passenger aircraft constitutes approximately $50 \%$ of air traffic. This figure increases gradually regarding the statistics in previous years (Kupfer et al., 2011). The main customers of combinational airlines are airfreight forwarders or service providers such as GSA (General Sales Agent). Clancy and colleagues estimated that shipping companies control $85 \%$ of the general airfreight retail distribution. However, in the opinion of Hellermann, this ratio is between $90 \%$ and $95 \%$ (Hellermann, 2006). With the change that started in the 1960s, most combinational airlines have intensified the work and resources for passenger transportation by implementing airfreight management as the second plan (Rhoades, 2016). In the civil aviation industry where the passenger transport strategy is used extensively, airfreight service providers have aspired to evaluate all the $10-15 \%$ percentage space left by the combinational airlines for using different strategies to increase this percentage (Allaz, 2004).

In general combinational airlines avoid competition with firms operating only in airfreight transportation. The first reason for avoidance from competition could harm existing business relationships. The second reason is related to the investments required for combinational airlines. Because most of the combinational airlines lack the necessary equipment to compete in the airfreight transportation market (Allaz, 2004). Such investments were not eligible under the strategies and commercial issues (Moorman, 2007). Though the strategies of airfreight carriers reduced the chance of combinational airlines to increase their market share. Airlines are combined with wide-body passenger aircraft because of having importance in empty areas for airfreight transportation which are used for airfreight and can ensure a supplemental resource of income at a marginal expense. Additional sources of income from airfreight transportation also play a crucial role in sustaining long term activities. For example, airfreight revenues of LATAM Airlines were accounted for $31 \%$ of all revenues (for the second quarter of 2011) and 35\% of all airfreights were transported near luggage with wide-body aircraft under the airfreight transportation strategy (Casadesus-Masanell \& Tarzijan, 2012). Besides this information, airfreight transportation is also characterized by marginal profits and cyclic strategies (Doganis, 2006). The maximum comeback on invested funds for passengers related to combinational airlines is rarely more than 5\% per year (International Air Transport Association, 2020), and this percentage is below the weighted average expense of funds like returns in other competitive industries (Button, 2003, 1996; Doganis, 2006). In brief combinational airlines can not ignore the airfreight market, even if it is not seen as a target job description or an attractive system. Developing sufficient strategies and knowledge of how to design proper business samples is important for a company to maintain its competitiveness and also improve its profitability (Porter, 2008). Under all these criteria, many publications about the strategies of passenger airlines were made methodological recommendations (Daft \& Albers, 2013; Lohmann \& Koo, 2013; Daft \& Albers, 2015; Pereira \& Caetano, 2015). Until today, academics have not cared much attention to thesis topics related to the airfreight industry. There are few research or research projects 
related to the airfreight tactics of combinational airlines and many types of research have not connection especially on business models (Magretta, 2002).

\section{The concept of business models in airfreight transportation}

Different business models have been defined for airfreight transportation. In general, the business model is the definition of an establishment strategy according to the principles of architecture, design, model, plan, method, supposition, conceptualization, or declaration (Morris et al., 2005). Although concurrence on the description of an employment model is lacking, most researchers could describe how business models are combined and transformed. This is about "How to reward by partners and who take the ownership of a company that generates value" for the customers and other stakeholders (Magretta, 2002). Despite this definition, finding a suitable business model has many risks (Morris et al., 2005). Researchers who wanted to solve these risky situations can recognize this definition as the basic structure blocks of an administration model.

Therefore, the issues were added about customer proposal, product value, profit margin, resource utilization, and key concepts to structure blocks of this administration model (Johnson et al., 2008). Finally, it was concluded that the value descent dimension was the core of the administration model. Keen and Qureshi (2006) argued in addition to the relevant views which an administration model is a tool to balance the value that needs to be established between the airline and the customer. All business model definitions have been structured by different views and expanded by compiling the thoughts put together over the years (Wikström et al., 2010). New publications have been published by many researchers to support and develop the business model definition and collection of all different views (Timmers, 1998; Leem et al., 2004; Mansfield, 2004; Osterwalder et al., 2005; Giaglis et al., 2006; Al-Debei \& Avison, 2010; Osterwalder \& Pigneur, 2010; CasadesusMasanell \& Ricart, 2011; DaSilva \& Trkman, 2014).

Firstly Osterwalder et al. (2005) and secondly Pigneur (Osterwalder \& Pigneur, 2010) summarized these views as: "'How an organization model composes its value, how it transmits this value and how the logic of this value applied". In addition to the opinion of Osterwalder and Pigneur (2010), a system was defined as how a company can fulfill its business model. When the three evaluations specified in this system are fulfilled, the business model can succeed. These evaluations are classified as:

1) examining the characteristic scope of the administration model,

2) determining the comparisons between business models with selecting which should have defined as the most appropriate,

3) 3) successfully applicate this model under the scope of airfreight transportation (Kalakou \& Macario, 2013; Quak et al., 2014; Reis \& Macario, 2015).

\section{Study objective and research methodology}

This study includes the data related to Total Airfreight Most Recent (2019) Value (million ton-km), Total GDP Most Recent (2019) Value (Current US\$), and Total Population Most Recent (2018) Value from 26 countries. Total Airfreight Most Recent Value includes both inbound and outbound passengers because of this, the data can not be separated into two types. In this study, all the data were taken from the World Bank Open Data (The World Bank, 2020).

The total airfreight and the total population are related to the total quantity of the most recent value like the gross domestic product. GDP is defined as the overall financial or market amount of whole the finished goods and services produced inside a country's boundaries in a particular period. As an extensive evaluation of total domestic production, it works as an exhaustive scorecard of an established country's economic welfare. However GDP is generally measured on an annual basis, it is sometimes calculated quarterly therewithal. In this study, GDP data was taken annually (Investopedia, 2020).

\section{ICAO council groups}

The ICAO Council is a union of the organization that liable to the assembly. It is formed of 36 Member States that elected by the assembly for 3 years. The mission of the ICAO Council is to represent the states of main significance in airfreight, the states which make the largest addition to the judgment of facilities for international civil air navigation, and the states whose assignment guarantees the geographical locations of the universe that are demonstrated on the council. The present Council was elected in October 2019. The following States were elected from among ICAO's 193 Member States to the Organization's 36 Member Governing Council during the 2019 ICAO Assembly. The structure of the present Council is as follows (International Civil Aviation Organization, 2020b):

\section{The group I states of main significance in air transport}

Australia, Brazil, Canada, China, France, Germany, Italy, Japan, Russian Federation, United Kingdom, and the United States.

The group II states which make the largest contribution to the judgment of facilities for international civil air navigation

Argentina, Colombia, Egypt, Finland ${ }^{*}$ India, Mexico, Netherlands*, Nigeria, Saudi Arabia, Singapore, South Africa, and Spain.

\section{The group III states providing geographical representation}

Costa Rica*, Côte d'Ivoire*, Dominican Republic*, Equatorial Guinea ${ }^{\star}$, Greece* ${ }^{\star}$ Malaysia, Paraguay ${ }^{\star}$, Peru$^{\star}$, Republic of Korea, Sudan*, Tunisia*, United Arab Emirates, Zambia*.

${ }^{*}$ States which were newly-included in 2019 (International Civil Aviation Organization (ICAO), 2019). 
In this study, 10 of the 11 countries are examined as main significant countries exclude Australia, 8 of the 12 countries are examined as large contribution countries exclude Costa Rica, Finland, Nigeria, and Singapore. Malaysia, Republic of Korea, Turkey, Thailand, Colombia, Indonesia, Philippines, and the Iran Islamic Republic are examined as geographical representation and other countries in the analysis. So, 20 of 26 countries took place in the ICAO Council Members, and 6 of them took place as others.

The establishment of the relationship between the ICAO council member countries and the top 50 countries in 3 different categories is important for the study. In this study, 20 of the 26 selected countries are members of the council. Besides, 10 of these 20 countries are in the main significance countries, and the relationship with airfreight has been demonstrated in a much more significant way thanks to the high GDPs due to the high-level economies of these countries.

\section{The selected countries}

The worlds' top 50 countries which ranked as total airfreight, gross domestic product (GDP), and total popula- tion are included in this study. Solely 26 countries have taken place in these three lists, and all of them included in the analysis. These countries are shown with their most recent values in Table 1 .

To summarize the parameters, the descriptive statistics of the data are shown in Table 2. The average of Total Airfreight Most Recent Value (million ton-km) is $5502.8+9326.9$, the average of Total GDP Most Recent Value (Current US\$) is 2734814.1+4725519.3, the average of Total Population Most Recent Value is $195710.01+356724.46$. The wide range of the parameters (max-min) shows that the variability is high and these parameters should be considered as splitting into ICAO council groups to reduce the variability. Also, the standard deviations are high and this metric is lead us to see the variability of the parameters. ICAO Council Groups are shown in 3 different categories such as main significance, large contribution, geographical representation, and other countries. Only the main significance countries' percentage is slightly higher.

There are 36 members of the ICAO Council. In this study 26 countries are examined and 20 of these countries are members of the ICAO Council. These are classified as;

Table 1. The ranking of countries for the selected parameters

\begin{tabular}{|c|c|c|c|c|c|}
\hline Rank & Region & Country & $\begin{array}{l}\text { Total Freight Most Recent } \\
\text { Value (million ton }-\mathrm{km} \text { ) }\end{array}$ & $\begin{array}{l}\text { Total GDP Most Recent } \\
\text { Value (Current US\$) }\end{array}$ & $\begin{array}{c}\text { Total Population Most } \\
\text { Recent Value }\end{array}$ \\
\hline 1 & 1 & United States & 42985 & 21427700.00 & 328239.52 \\
\hline 2 & 2 & China & 25256 & 14342902.84 & 1397715.00 \\
\hline 3 & 2 & Japan & 9421 & 5081769.54 & 126264.93 \\
\hline 4 & 3 & Germany & 7970 & 3845630.03 & 83132.80 \\
\hline 5 & 3 & Russian Federation & 6811 & 1699876.58 & 144373.54 \\
\hline 6 & 3 & United Kingdom & 6198 & 2827113.18 & 66834.40 \\
\hline 7 & 3 & Turkey & 5949 & 754411.71 & 83429.62 \\
\hline 8 & 3 & France & 4444 & 2715518.27 & 67059.89 \\
\hline 9 & 2 & India & 2704 & 2875142.31 & 1366417.75 \\
\hline 10 & 2 & Thailand & 2666 & 543649.98 & 69625.58 \\
\hline 11 & 1 & Brazil & 1846 & 1839758.04 & 211049.53 \\
\hline 12 & 3 & Italy & 1418 & 2001244.39 & 60297.40 \\
\hline 13 & 2 & Republic of Korea & 11930 & 1642383.22 & 51709.10 \\
\hline 14 & 1 & Canada & 3434 & 1736425.63 & 37589.26 \\
\hline 15 & 2 & Malaysia & 1404 & 364701.52 & 31949.78 \\
\hline 16 & 1 & Colombia & 1349 & 323802.81 & 50339.44 \\
\hline 17 & 2 & Indonesia & 1132 & 1119190.78 & 270625.57 \\
\hline 18 & 3 & Spain & 1117 & 1394116.31 & 47076.78 \\
\hline 19 & 1 & Mexico & 1090 & 1258286.72 & 127575.53 \\
\hline 20 & 2 & Saudi Arabia & 1085 & 792966.84 & 34268.53 \\
\hline 21 & 2 & Philippines & 836 & 376795.51 & 108116.62 \\
\hline 22 & 2 & South Africa & 716 & 351431.65 & 58558.27 \\
\hline 23 & 2 & Egypt, Arab Rep. & 438 & 303175.13 & 100388.07 \\
\hline 24 & 1 & Argentina & 312 & 449663.45 & 44938.71 \\
\hline 25 & 2 & Iran, Islamic Republic & 291 & 445345.28 & 82913.91 \\
\hline 26 & 3 & Poland & 271 & 592164.40 & 37970.87 \\
\hline
\end{tabular}


Table 2. Descriptive statistics of the variables

\begin{tabular}{|c|c|c|c|}
\hline & Variables & Mean \pm SD & Med (Min-Max) \\
\hline Total Airfreight & ost Recent Value (million ton - km) & $5502.8 \pm 9326.9$ & $1632(271-42985)$ \\
\hline Total GDP Mos & ecent Value (Current US\$) & $2734814.1 \pm 4725519.3$ & $1326201.5(303175.1-21427700)$ \\
\hline Total Populatio & lost Recent Value & $195710.01 \pm 356724.46$ & $76269.74(31949.78-1397715.0)$ \\
\hline & & $\mathrm{N}$ & $\%$ \\
\hline ICAO Council & Region 1 Main significance countries & 10 & 38.5 \\
\hline & Region 2 Large contribution countries & 8 & 30.8 \\
\hline & $\begin{array}{l}\text { Region } 3 \text { Geographical representation and } \\
\text { the other countries }\end{array}$ & 8 & 30.8 \\
\hline
\end{tabular}

The United States, China, Japan, Germany, the Russian Federation, the United Kingdom, France, Brazil, Italy, and Canada are the countries of main significance. Solely Australia is not added to that list.

India, Colombia, Spain, Mexico, Saudi Arabia, South Africa, Egypt Arab Rep, and Argentina are the countries of large contributions.

Besides, South Korea and Malaysia are the countries of geographical representation. Turkey, Thailand, Indonesia, the Philippines, Iran Islamic Republic, and Poland are the countries that did not place as members of the ICAO Council, but they took place in the analysis.

As a result, 20 of the 26 countries evaluated in the study continue their activities as members of the ICAO Council, and therefore during the evaluation, a review was made based on the ICAO council members.

\section{Methodology for statistical analysis}

The normality test was done with the Shapiro-Wilk test. Non-parametric statistical methods were used for values with skewed (nonnormally distributed, Shapiro-Wilk p > 0.05) distribution. Descriptive statistics were presented using mean, standard deviation, median (and minimummaximum) for the continuous variables. For comparison of two non-normally distributed independent groups, the

Mann-Whitney U test was used. For comparison of more than two non-normally distributed independent groups, the Kruskal Wallis test was used. To show the differences between parameters and ICAO Council groups, the Kruskal Wallis test was applied. Kruskal Wallis test is a comparison method of medians. Kruskal and Wallis (1952) proposed T statistics based on ranks $\left(R_{i}\right)$ of the parameter which is given below:

$$
T=\frac{12}{N(N+1)} \sum_{i=1}^{k} \frac{R_{i}}{n_{i}}-3(N+1) .
$$

In equation (1), $\mathrm{k}$ is the number of groups, $\mathrm{N}$ is the size of the sample and $\mathrm{n} \_\mathrm{i}$ is the sample size per group. The statistical significance was accepted when the two-sided $p$-value was lower than 0.05. After compared 3 ICAO Council groups, the significant results should be considered pairwise to show which group has a significant effect. To find the pairwise relationships Mann-Whitney $U$ test is used and the significance level is redetermined with Bonferroni correction (Table 3). The statistical significance was accepted when the two-sided $p$-value was lower than 0.016 according to Bonferroni correction (0.05/number of comparisons). Mann and Whitney (1947) proposed U statistics based on ranks ( $\left.R \_i\right)$ of the parameter which is given below:

$$
\begin{aligned}
& U_{1}=\sum R_{1}-\frac{n_{1}\left(n_{1}+1\right)}{2} ; \\
& U_{2}=\sum R_{2}-\frac{n_{2}\left(n_{2}+1\right)}{2} .
\end{aligned}
$$

In equations (2.1) and (2.2), $n_{1}$ and $n_{2}$ are the sample size of each two groups. $R_{1}$ and $R_{2}$ are the ranks of each two groups.

Spearman's correlation analysis was used to determine the significant correlation between Total Airfreight Most Recent Value (million ton-km) and Total GDP Most Recent Value (Current US\$), Total Population Most Recent Value. The correlation analysis can be considered as a pre-variable selection technique for regression analysis in this study (Table 4). Spearman's correlation analysis is based on ranks like the other nonparametric statistical methods. The correlation coefficient's formula is given in Equation (3) (Chen \& Popovich, 2002).

$$
r_{s}=\frac{\sum_{i=1}^{n}\left(R_{x i}-\overline{R_{x \mathrm{i}}}\right)\left(R_{y i}-\overline{R_{y \mathrm{i}}}\right)}{\sum_{i=1}^{n}\left(R_{x i}-\overline{R_{x \mathrm{i}}}\right)^{2} \sum_{i=1}^{n}\left(R_{y i}-\overline{R_{y \mathrm{i}}}\right)^{2}} .
$$

The significant correlations between Total Airfreight Most Recent Value (million ton- $\mathrm{km}$ ) and the others are taken as independent variables in the Multiple Regression Model. The model is used to show the effect of parameters on Total Airfreight Most Recent Value (million ton-km). Multiple Linear Regression model assumptions (normality of the residuals, heteroscedasticity, and autocorrelation) are provided using the Durbin Watson test $(\mathrm{DW} \approx 2)$, Variance Inflation Factor $(\mathrm{VIF})(\mathrm{VIF}<10)$, and residual plots (random distributed). The beta coefficients show the change of 1 unit in an independent variable how affects a dependent variable (Table 5). 
Multidimensional scaling (MDS) is used for a visual representation of distances or dissimilarities between sets of countries (Kruskal \& Wish, 1978). Countries that are more similar (or have shorter distances) are closer together on the graph than objects that are less similar (or have longer distances). As well as interpreting dissimilarities as distances on a graph, MDS can also serve as a dimension reduction technique for high-dimensional data (Buja et al., 2008). In this study, the similarities were calculated by using Euclidean Distance, and three variables came down to two dimensions. The Euclidean distance matrix was converted to the configuration by IsoplotR (Figure 1). Statistical analysis was performed by using the MedCalc Statistical Software version 12.7.7 (MedCalc, 2013) and R (smack of the package).

\section{Results}

To investigate the difference between council groups in terms of the variables, univariate analysis is utilized (Table 3).

There is a statistically significant difference between council groups in terms of Total Airfreight Most Recent
Value (million ton-km) and Total GDP Most Recent Value (Current US\$) (Kruskal Wallis $p<0.05$ ). According to posthoc pairwise comparisons results, there is a statistically significant difference between chief importance and large contributions countries in terms of Total Airfreight Most Recent Value (million ton-km) and Total GDP Most Recent Value (Current US\$). The average of chief importance countries is found higher than large contribution countries. Moreover, there is a statistically significant difference between chief importance countries and geographic representation and the other countries in terms of Total Airfreight and Total GDP Most Recent Value (Current US\$). The average of chief importance is found higher than geographical representation and others.

According to correlation analysis, there is a statistically significant positive strong correlation between Total Airfreight Most Recent Value (million ton-km) and Total GDP Most Recent Value (Current US\$) $(r=0.776$, $p<0.001)$. Also, it is found that there is a statistically significant moderate correlation between Total Airfreight Most Recent Value (million ton-km) and Total Population Most Recent Value $(r=0.393, p=0.047)$ (Table 4).

Table 3. Comparisons according to council

\begin{tabular}{|c|c|c|c|c|}
\hline \multirow{2}{*}{ Variables } & Chief importance & Large contributions & $\begin{array}{l}\text { Geographic representation } \\
\text { and others }\end{array}$ & \multirow{2}{*}{$p$} \\
\hline & $\begin{array}{c}\text { Mean } \pm \text { SD } \\
\text { Med (Min-Max) }\end{array}$ & $\begin{array}{c}\text { Mean } \pm \text { SD } \\
\text { Med (Min-Max) }\end{array}$ & $\begin{array}{c}\text { Mean } \pm \text { SD } \\
\text { Med (Min-Max) }\end{array}$ & \\
\hline $\begin{array}{l}\text { Total Airfreight Most Recent } \\
\text { Value (million ton }-\mathrm{km} \text { ) }\end{array}$ & $\begin{array}{c}10978.3 \pm 13141.9 \\
6504.5(1418-42985)\end{array}$ & $\begin{array}{c}1101.38 \pm 740.85 \\
1087.5(312-2704)\end{array}$ & $\begin{array}{c}3059.88 \pm 4036.09 \\
1268(271-11930)\end{array}$ & 0.002 \\
\hline $\begin{array}{l}\text { Total GDP Most Recent Value } \\
\text { (Current US\$) }\end{array}$ & $\begin{array}{c}5751793.85 \pm 6694177.97 \\
2771315.73(1699876.58- \\
21427700)\end{array}$ & $\begin{array}{c}968573.15 \pm 881514.82 \\
621315.15(303175.13- \\
2875142.31)\end{array}$ & $\begin{array}{c}729830.3 \pm 443598.59 \\
567907.19(364701.52- \\
1642383.22)\end{array}$ & $<0.001$ \\
\hline $\begin{array}{l}\text { Total Population Most Recent } \\
\text { Value }\end{array}$ & $\begin{array}{c}10978.3 \pm 13141.9 \\
6504.5(1418-42985)\end{array}$ & $\begin{array}{c}1101.38 \pm 740.85 \\
1087.5(312-2704)\end{array}$ & $\begin{array}{c}3059.88 \pm 4036.09 \\
1268(271-11930)\end{array}$ & 0.330 \\
\hline $\begin{array}{l}\text { Post-hoc pairwise comparisons } \\
\left(p^{\star}\right)\end{array}$ & $\begin{array}{l}\text { Chief importance vs. Large } \\
\text { contributions }\end{array}$ & $\begin{array}{l}\text { Chief importance vs. } \\
\text { Geographic representation } \\
\text { and others }\end{array}$ & $\begin{array}{l}\text { Large contributions vs. } \\
\text { Geographic representation } \\
\text { and others }\end{array}$ & \\
\hline $\begin{array}{l}\text { Total Airfreight Most Recent } \\
\text { Value (million ton }-\mathrm{km} \text { ) }\end{array}$ & $<0.001$ & 0.021 & 0.505 & \\
\hline $\begin{array}{l}\text { Total GDP Most Recent Value } \\
\text { (Current US\$) }\end{array}$ & 0.001 & $<0.001$ & 0.959 & \\
\hline
\end{tabular}

Note: Kruskal Wallis test, ${ }^{*}$ Mann-Whitney U test.

Table 4. Correlation analysis results

\begin{tabular}{|l|c|c|c|}
\hline \multicolumn{1}{|c|}{$r, p$} & $\begin{array}{c}\text { Total Airfreight Most Recent } \\
\text { Value (million ton - km) }\end{array}$ & $\begin{array}{c}\text { Total GDP Most Recent Value } \\
\text { (Current US\$) }\end{array}$ & $\begin{array}{c}\text { Total Population Most } \\
\text { Recent Value }\end{array}$ \\
\hline $\begin{array}{l}\text { Total Airfreight Most Recent Value } \\
(\text { million ton - km) }\end{array}$ & 1.000 & $0.776,<0.001$ & $0.393,0.047$ \\
\hline $\begin{array}{l}\text { Total GDP Most Recent Value } \\
\text { (Current US\$) }\end{array}$ & $0.776,<0.001$ & 1,000 & $0.454,0.020$ \\
\hline Total Population Most Recent Value & $0.393,0.047$ & $0.454,0.020$ & 1,000 \\
\hline
\end{tabular}


Table 5. Regression analysis results against airfreight (ton-km)

\begin{tabular}{|l|c|c|c|c|c|c|}
\hline \multicolumn{2}{|c|}{ Independent Variables } & $R^{2}$ & Adjusted $R^{2}$ & Durbin - Watson & $p$ & $F$ \\
\hline Model & Unstandardized $\beta$ & Standard Error & Standardized $\beta$ & $\mathrm{t}$ & $\mathrm{p}$ & VIF \\
\hline & 567.539 & 550.501 & & 1.031 & 0.313 & \\
\hline Constant & 0.002 & 0.000 & 1.019 & 17.876 & $<0.001$ & 1.298 \\
\hline $\begin{array}{l}\text { Total GDP Most Recent } \\
\text { Value (Current US\$) }\end{array}$ & -0.003 & 0.001 & -0.110 & -1.933 & 0.066 & 1.298 \\
\hline $\begin{array}{l}\text { Total Population Most } \\
\text { Recent Value }\end{array}$ & & & & & & \\
\hline
\end{tabular}

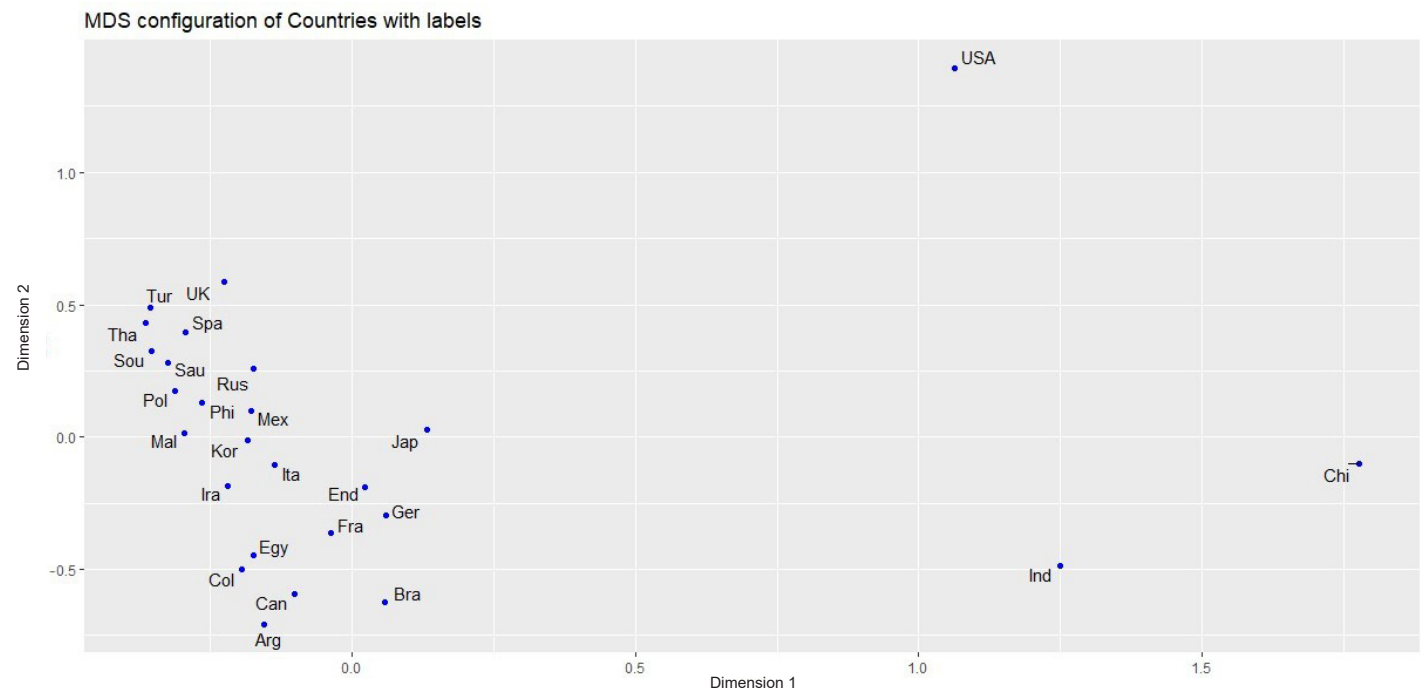

Note: ${ }^{\star}$ Indonesia is described as End to differenciate from India.

Figure 1. MDS configuration of countries with labels

Therefore, Total Population Most Recent Value and Total GDP Most Recent Value (Current US\$) are selected as independent variables in multiple linear regression analysis. To evaluate the impact of Total GDP Most Recent Value (Current US\$) and Total Population Most Recent Value on Total Airfreight Most Recent Value (million ton- $\mathrm{km}$ ), a multiple regression model was performed (Table 5).

Total GDP Most Recent Value (Current US\$), and Total Population Most Recent Value are considered as the independent variables that could affect the Total Airfreight Most Recent Value (million ton- $\mathrm{km}$ ). Since the DurbinWatson value is 2.314 , there is no autocorrelation. The model is statistically significant $(F=188.299, p<0.001)$ and can be interpreted. Total GDP Most Recent Value (Current US\$) is found statistically significant at a $95 \%$ confidence level and Total Population Most Recent Value is found statistically significant at a $90 \%$ confidence level. It can be said that a change of 1 unit in a Total GDP Most Recent Value (Current US\$) increases Total Airfreight Most Recent Value by 0.002 million ton-km. It can be said that a change of 1 unit in a Total Population Most Recent Value decreases Total Airfreight Most Recent Value by 0.003 million ton-km.
According to Table 4, the total population slightly harms Total Airfreight Most Recent Value as it can be specified as a moderate correlation. Furthermore, the total population and the total airfreight show a moderate positive correlation, whereas the regression result shows a negative impact. Because the correlation coefficient is low and just indicates a binary relationship, the regression result can be interpreted and includes more information having multiple parameters. To investigate the negative impact of the population in regression analysis, residuals are determined. So, it is seen that the United States, China, and India are the leverage points. To see the location of these countries on the graph, MDS is performed without removing the countries from the analysis.

A metric multidimensional scale is used to show the similarities between the countries (Figure 1). First of all, the stress- 1 value equals 0.059 which is acceptable $(0.05$ good fit) (Borg \& Groenen, 2005). As can be seen in Figure 1, the United States, India, and China are outliers for two dimensions. However, the United States and China are positioned as the three most outliers. These countries are far from each other which means they are different in terms of Total Airfreight Most Recent Value (million ton$\mathrm{km}$ ), Total GDP Most Recent Value (Current US\$), and 
Total Population Most Recent Value. According to Table 3, the result is supported by the MDS results that placed in a separate region as outliers (Main significance countries: United States, China, and large contribution country: India). According to the MDS graph, Turkey and the UK have similarities in terms of total airfreight. It is obvious that the USA is the best country having the highest Airfreight Most Recent Value (million ton-km), Total GDP Most Recent Value (Current US\$). Although the USA is placed in the third-place of Total Population Most Recent Value, its position can be seen clearly on the top righthand side of the MDS graph with the first ranking of total airfreight, and total GDP. So, Figure 1 is more related to dimension 1 (D1) which shows the total population as it can be seen that the United States, China, and India are differentiated from other countries. Dimension 2 (D2) is more related to the total airfreight and total GDP as it can be seen that the United Kingdom and Turkey are differentiated from other countries too.

\section{Conclusions and recommendations}

In this study after defining the term of airfreight, a general evaluation was made with correlation analysis according to examining relationships between total airfreight, total gross domestic product, and total population. In addition to airfreight on a general basis, it was also mentioned that civil aviation is considered under the concept of combinational airlines which is related to carrying airfreight near luggage in commercial flights. Since the beginning of the 2000s, airfreight has increased by $4.5-5 \%$ percentage every year all over the world. Airlines play an important role in this increase. Airlines have taken place in the process as the main providers of airfreight due to the implementation of the airport-to-airport transport strategy. In this process; there are airfreight forwarders, airfreight companies, customs procedures, airfreight terminals, and ground handling companies. In the airfreight system; the first process is implemented between customs and other transactions. These are classified as; preparation, packaging, and loading stages of airfreight. Rather than examining the major development trend of civil aviation yearly (which is already a known fact), it is thought that examining the countries with GDP and total population under the data of total airfreight would provide a more scientific conclusion.

As a result of univariate analysis, correlation, multiple linear regression, and multidimensional scaling analyzes are applied for this purpose. GDP has a positive effect on airfreight, while the total population has a moderate effect. Therefore as countries grow stronger economically, this upward trend has a positive impact on total airfreight. However, there is a moderate relationship between the total population and total airfreight. For example; the selected 26 countries' total airfreight was equal to $64.8 \%(143,073$ million ton-km) when the world's total airfreight was equal to 220,707 million ton- $\mathrm{km}$ at the end of the year 2018. Simi- larly, the selected 26 countries' total population was equal to $66.3 \%$ ( 5.088 billion) when the world's total population was equal to 7.674 billion at the end of the year 2019. However, the selected 26 countries' total GDP (71.105 trillion) was equal to $81 \%$ when the world's total GDP was equal to 87.752 trillion at the end of the year 2019 .

The comparisons of ICAO Council Countries show that the ICAO Council Chief Importance Countries have higher airfreight and GDP values than other ICAO Council Countries. In the ICAO reports the council countries are diversified into three sections, the first section is obtained as Chief Importance Countries such as the United States, Japan, Germany, the United Kingdom, Canada, etc. There has a strong relationship between the selected parameters. This strong relationship reveals that there has a positive correlation. It is seen that when the total GDP is increased also total airfreight numbers are increased too. These numbers show that GDP has a positive impact on total airfreight numbers exclude the total population with having a moderate effect. According to the MDS configuration of countries, some of the main significant countries were differentiated from other countries. These countries are classified as; the United States, China, Japan, Germany, Brazil, and France. Furthermore, in the MDS configuration of countries, India and Indonesia are placed similar to the main significant countries but they existed on the large contribution country list of the ICAO.

In future studies, the number of three variables that were examined can be increased and air cargo companies can be examined with multi-dimensional scaling instead of countries.

\section{Disclosure statement}

The authors declare that there is no conflict of interest. In this study, there is no need for ethics committee approval because of using open source databases.

\section{References}

Airbus. (2014). Airbus GMF Booklet 2014-2033. Blagnac Cedec, France.

Al-Debei, M. M., \& Avison, D. (2010). Developing a unified framework of the business model concept. European Journal of Information Systems, 19(3), 359-376. https://doi.org/10.1057/ejis.2010.21

Allaz, C. (2004). The history of airfreight and airmail from the 18th century. Christopher Foyle Publishing.

Alves, V., \& Forte, R. (2015). A Cournot model for analysing the effects of an open skies agreement. Journal of Air Transport Management, 42, 125-134.

https://doi.org/10.1016/j.jairtraman.2014.09.007

Artar, O. K., Uca, N., \& Tasçi, M. E. (2016). The impact of the airline freight transportation on GDP in Turkey. Journal of International Trade, Logistics and Law, 2(2), 143.

Boeing. (2014). Boeing current market outlook 2014. Seattle, USA.

Borg, I., \& Groenen, P. J. F. (2005). Springer series in statistics. Modern multidimensional scaling: Theory and applications (2nd ed.). Springer Science + Business Media. 
Buja, A., Swayne, D. F., Littman, M. L., Dean, N., Hofmann, H., \& Chen, L. (2008). Data visualization with multidimensional scaling. Journal of Computational and Graphical Statistics, 17(2), 444-472. https://doi.org/10.1198/106186008X318440

Button, K. (2003). Does the theory of the 'core' explain why airlines fail to cover their long-run costs of capital? Journal of Air Transport Management, 9(1), 5-14.

https://doi.org/10.1016/S0969-6997(02)00075-3

Button, K. (1996). Liberalising European aviation: is there an empty core problem? Journal of Transport Economics and Policy, 30(3), 275-291.

Casadesus-Masanell, R., \& Ricart, J. E. (2011). How to design a winning business model. Harvard Business Review, 89(1/2), 100-107.

Casadesus-Masanell, R., \& Tarzijan, J. (2012). When one business model isn't enough: LAN airlines flourishes by running three distinctly different operations at the same time. Harvard Business Review, 90(1/2), 132.

Chan, F. T., Bhagwat, R., Kumar, N., Tiwari, M. K., \& Lam, P. (2006). Development of a decision support system for air-airfreight pallets loading problem: A case study. Expert Systems with Applications, 31(3), 472-485.

https://doi.org/10.1016/j.eswa.2005.09.057

Chao, C. C., \& Li, R. G. (2017). Effects of airfreight types and load efficiency on airline airfreight revenues. Journal of Air Transport Management, 61, 26-33.

https://doi.org/10.1016/j.jairtraman.2015.11.006

Chen, P. Y., \& Popovich, P. M. (2002). Quantitative applications in the social sciences: Correlation. SAGE Publications Ltd. https://doi.org/10.4135/9781412983808

Clutch. (2020). Air freight companies. https://clutch.co/logistics/ air-freight-companies

Daft, J., \& Albers, S. (2013). A conceptual framework for measuring airline business model convergence. Journal of Air Transport Management, 28, 47-54.

https://doi.org/10.1016/j.jairtraman.2012.12.010

Daft, J., \& Albers, S. (2015). An empirical analysis of airline business model convergence. Journal of Air Transport Management, 46, 3-11. https://doi.org/10.1016/j.jairtraman.2015.03.008

DaSilva, C. M., \& Trkman, P. (2014). Business model: What it is and what it is not. Long Range Planning, 47(6), 379-389. https://doi.org/10.1016/j.lrp.2013.08.004

Doganis, R. (2006). The airline business. Psychology Press. https://doi.org/10.4324/9780203596807

Feng, B., Li, Y., \& Shen, Z. J. M. (2015). Air cargo operations: Literature review and comparison with practices. Transportation Research Part C: Emerging Technologies, 56, 263-280. https://doi.org/10.1016/j.trc.2015.03.028

Giaglis, G. M., Kallio, J., Tinnilä, M., \& Tseng, A. (2006). An international comparison of operator-driven business models. Business Process Management Journal, 12(3), 281-298. https://doi.org/10.1108/14637150610667962

Han, D. L., Tang, L. C., \& Huang, H. C. (2010). A Markov model for single-leg airfreight revenue management under a bid-price policy. European Journal of Operational Research, 200(3), 800-811. https://doi.org/10.1016/j.ejor.2009.02.001

Hellermann, R. (2006). Capacity options for revenue management: theory and applications in the airfreight industry (Vol. 575). Springer Science \& Business Media.

Huang, K., \& Chang, K. C. (2010). An approximate algorithm for the two-dimensional airfreight revenue management problem. Transportation Research Part E: Logistics and Transportation Review, 46(3), 426-435.

https://doi.org/10.1016/j.tre.2009.09.003
International Air Transport Association (IATA). (2020). Cargo capacity crunch: demand plummets but capacity disappears even faster. https://www.iata.org/en/pressroom/pr/2020-06-02-01/

International Civil Aviation Organization (ICAO). (2019). Council States 2019-2022. https://www.icao.int/about-icao/Council/Pages/council-states-2019-2022.aspx

International Civil Aviation Organization (ICAO). (2020a). ICAO Assembly elects new Council for three-year term. www.icao.int

International Civil Aviation Organization (ICAO). (2020b). The ICAO Council. https://www.icao.int/about-icao/Council/Pages/council.aspx

Investopedia. (2020). Gross Domestic Product (GDP). https://www.investopedia.com/terms/g/gdp.asp

Johnson, M. W., Christensen, C. M., \& Kagermann, H. (2008). Reinventing your business model. Harvard Business Review, 86(12), 57-68.

Kalakou, S., \& Macário, R. (2013). An innovative framework for the study and structure of airport business models. Case Studies on Transport Policy, 1(1-2), 2-17.

https://doi.org/10.1016/j.cstp.2013.09.001

Kasilingam, R. G. (1996). Airfreight revenue management: characteristics and complexities. European Journal of Operational Research, 96(1), 36-44. https://doi.org/10.1016/0377-2217(95)00329-0

Keen, P., \& Qureshi, S. (2006, January). Organizational transformation through business models: a framework for business model design. In Proceedings of the 39th Annual Hawaii International Conference on System Sciences (HICSS'06), Vol. 8 (pp. 206b-206b). IEEE. https://doi.org/10.1109/HICSS.2006.376

Kruskal, W. H., \& Wallis, W. A. (1952). Use of ranks in onecriterion variance analysis. Journal of the American Statistical Association, 47(260), 583-621. https://doi.org/10.1080/01621459.1952.10483441

Kruskal, J. B., \& Wish, M. (1978). Multidimensional scaling: Sage university papers: Quantitative applications in the social sciences. Sage University Paper Series on Quantitative Applications in the Social Sciences, No. 07-011. Sage Publications.

Kupfer, F., Meersman, H., Onghena, E., \& Van de Voorde, E. (2011). Airfreight and merchandise trade: towards a disaggregated analysis. Journal of Air Transport Studies, 2(2), 28-48. https://doi.org/10.38008/jats.v2i2.99

Leem, C. S., Suh, H. S., \& Kim, D. S. (2004). A classification of mobile business models and its applications. Industrial $\mathrm{Ma}$ nagement \& Data Systems, 104(1). https://doi.org/10.1108/02635570410514115

Lohmann, G., \& Koo, T. T. (2013). The airline business model spectrum. Journal of Air Transport Management, 31, 7-9. https://doi.org/10.1016/j.jairtraman.2012.10.005

Lurkin, V., \& Schyns, M. (2015). The airline container loading problem with pickup and delivery. European Journal of Operational Research, 244(3), 955-965.

https://doi.org/10.1016/j.ejor.2015.02.027

Magretta, J. (2002). Why business models matter. Harvard Business Review, 80(5), 86-133.

Mann, H. B., \& Whitney, D. R. (1947). On a test of whether one of two random variables is stochastically larger than the other. The Annals of Mathematical Statistics, 18(1), 50-60. https://doi.org/10.1214/aoms/1177730491

Mansfield, B. (2004). Competence in transition. Journal of European Industrial Training, 28, 296-309. https://doi.org/10.1108/03090590410527672

MedCalc. (2013). MedCalc Statistical Software version 19.2.6. MedCalc Software Ltd, Ostend, Belgium. https://www.medcalc.org 
Moorman, R. (2007). Rejuvenating airfreight. Airfreight World.

Morrell, P. S. (2012). Moving boxes by air: the economics of international airfreight. Ashgate Publishing, Ltd.

Morris, M., Schindehutte, M., \& Allen, J. (2005). The entrepreneur's business model: toward a unified perspective. Journal of Business Research, 58(6), 726-735. https://doi.org/10.1016/j.jbusres.2003.11.001

Osterwalder, A., \& Pigneur, Y. (2010). Business model generation: a handbook for visionaries, game changers, and challengers. John Wiley \& Sons.

Osterwalder, A., Pigneur, Y., \& Tucci, C. L. (2005). Clarifying business models: Origins, present, and future of the concept. Communications of the Association for Information Systems, 16(1), 1-25. https://doi.org/10.17705/1CAIS.01601

Pereira, B. A., \& Caetano, M. (2015). A conceptual business model framework applied to air transport. Journal of Air Transport Management, 44-45, 70-76. https://doi.org/10.1016/j.jairtraman.2015.02.006

Poret, M. D., O'Connell, J. F., \& Warnock-Smith, D. (2015). The economic viability of longhaul low cost operations: evidence from the transatlantic market. Journal of Air Transport Management, 42, 272-281. https://doi.org/10.1016/j.jairtraman.2014.11.007

Porter, M. E. (2008). The five competitive forces that shape strategy. Harvard Business Review, 86(1), 78.

Quak, H., Balm, S., \& Posthumus, B. (2014). Evaluation of city logistics solutions with business model analysis. Procedia Social and Behavioral Sciences, 125, 111-124. https://doi.org/10.1016/j.sbspro.2014.01.1460
Reis, V., \& Macário, R. (2015). Promoting integrated passenger transport solutions using a business approach. Case Studies on Transport Policy, 3(1), 66-77. https://doi.org/10.1016/j.cstp.2014.08.002

Rhoades, D. L. (2016). Evolution of international aviation: Phoenix rising. Routledge. https://doi.org/10.4324/9781315581361

Saloodo. (2020). Air freight. https://www.saloodo.com/logisticsdictionary/air-freight/

The World Bank. (2020). https://data.worldbank.org

Timmers, P. (1998). Business models for electronic markets. Electronic Markets, 8(2), 3-8. https://doi.org/10.1080/10196789800000016

Vancroonenburg, W., Verstichel, J., Tavernier, K., \& Berghe, G. V. (2014). Automatic airfreight selection and weight balancing: a mixed integer programming approach. Transportation Research Part E: Logistics and Transportation Review, 65, 70-83. https://doi.org/10.1016/j.tre.2013.12.013

Wang, J. J., \& Heinonen, T. H. (2015). Aeropolitics in East Asia: an institutional approach to air transport liberalization. Journal of Air Transport Management, 42, 176-183. https://doi.org/10.1016/j.jairtraman.2014.10.002

Wikström, K., Artto, K., Kujala, J., \& Söderlund, J. (2010). Business models in project business. International Journal of Project Management, 28(8), 832-841.

https://doi.org/10.1016/j.ijproman.2010.07.001

Yan, S., Shih, Y. L., \& Shiao, F. Y. (2008). Optimal airfreight container loading plans under stochastic demands for air express carriers. Transportation Research Part E: Logistics and Transportation Review, 44(3), 555-575. https://doi.org/10.1016/j.tre.2007.01.006 